\title{
Mengukur Kepemimpinan Perempuan di Indonesia dengan Metode Fuzzy c-Means Clustering
}

\author{
SUKIM ${ }^{1}$, FIRDAUS, RETNANINGSIH, EFRI DIAH UTAMI \\ 1Sekolah Tinggi Ilmu Statistik \\ e-mail: 1sukim@stis.ac.id
}

\begin{abstract}
ABSTRAK
Indonesia is fully committed to implement Sustainable Development Goals (SDGs). The goal 5 of SDGs priorities the need to end discrimination against women and girls in all forms, and meeting their right to equal opportunities in employment, health and education. It is in line with the Presidential Instruction No. 9/2000 on gender mainstreaming in the National development programs. According to the result of the 2015 Intercensal Population census, about 49.75 percent of 255.18 million Indonesian population are women. This large figure population of women could be an asset for the national development in Indonesia when they are given the opportunity to advance and improve their quality. Unfortunately, it is realized that there is still a gap between men and women in Indonesia due to limited access of women in education, employment, politics and high governmental position. Considering that women's leadership is important to achieve and accelerate SDGs, this paper aims to assess women's leadership in Indonesia at province level by using 5 dimensions of women's leadership (politics, government, education, economy and decision making). Applying Fuzzy c-Means Clustering Method and 7 validity indexes, the result found that provinces in Indonesia can be grouped into 4 clusters. The fourth cluster consists of 14 provinces and is considered as a cluster with lowest women's leadership.
\end{abstract}

Kata Kunci: Women's Leadership, Fuzzy c-Means Clustering, Sustainable Development.

\section{PENDAHULUAN}

Pada tahun 2015, negara-negara di dunia terutama yang merupakan anggota PBB menyepakati beberapa Tujuan pembangunan berkelanjutan atau sebagai Sustainable Development Goals (SDGs). SDGs yang memuat 17 tujuan dan 169 target ini dimulai tahun 2016 dan menargetkan tahun 2030 sebagai tahun pencapaian target tujuannya. Dalam SDGs ini, mencapai kesetaraan gender dan pemberdayaan perempuan menjadi tujuan tersendiri dan tercantum sebagai tujuan ke-5 yaitu "Ensuring women's full and effective participation and equal opportunities for leadership at all levels of decision-making in political, economic and public life".

Kesetaraan gender dan pemberdayaan perempuan menjadi target penting dalam pembangunan manusia baik pada tingkat global maupun di tingkat nasional di Indonesia karena dapat meningkatkan daya saing negara dan pembangunan. Kesetaraan gender adalah kesamaan kondisi bagi laki-laki dan perempuan untuk memperoleh kesempatan dan hak-haknya sebagai manusia, agar mampu ikut berpartisipasi dalam berbagai kegiatan seperti kegiatan politik, ekonomi, sosial budaya dan lain sebagainya. Upaya mencapai kesetaraan gender ini sejalan dengan UU No. 7 Tahun 1984 tentang kesepakatan internasional untuk penghapusan segala bentuk diskriminasi terhadap perempuan (The Convention on Elimination of all forms of Discrimination Against Woman) dan Instruksi Presiden No. 9 Tahun 2000 tentang pengarusutamaan gender dalam pembangunan nasional.

Salah satu ukuran tingkat keberhasilan pembangunan yang mencakup isu gender adalah Indeks Pembangunan Gender (IPG) yang menggambarkan kesetaraan gender di bidang pendidikan, kesehatan dan ekonomi. Secara nasional pada tahun 2013 IPG telah mencapai 69,57 dengan IPG tertinggi terjadi di Provinsi DKI Jakarta dengan nilai IPG 74,98 (Buku Saku Indonesia, 2015). Meskipun demikian disadari bahwa masih ada kesenjangan pembangunan 
102 Sukim, dkk.

antara pria dan wanita di Indonesia karena terbatasnya akses perempuan terhadap fasilitas kesehatan yang lebih baik, pendidikan lebih tinggi, pekerjaan, politik dan posisi pemerintahan yang tinggi. Terbukti hanya 8 provinsi yang memiliki IPG di atas nilai rata-nata nasional (lihat Gambar 1).

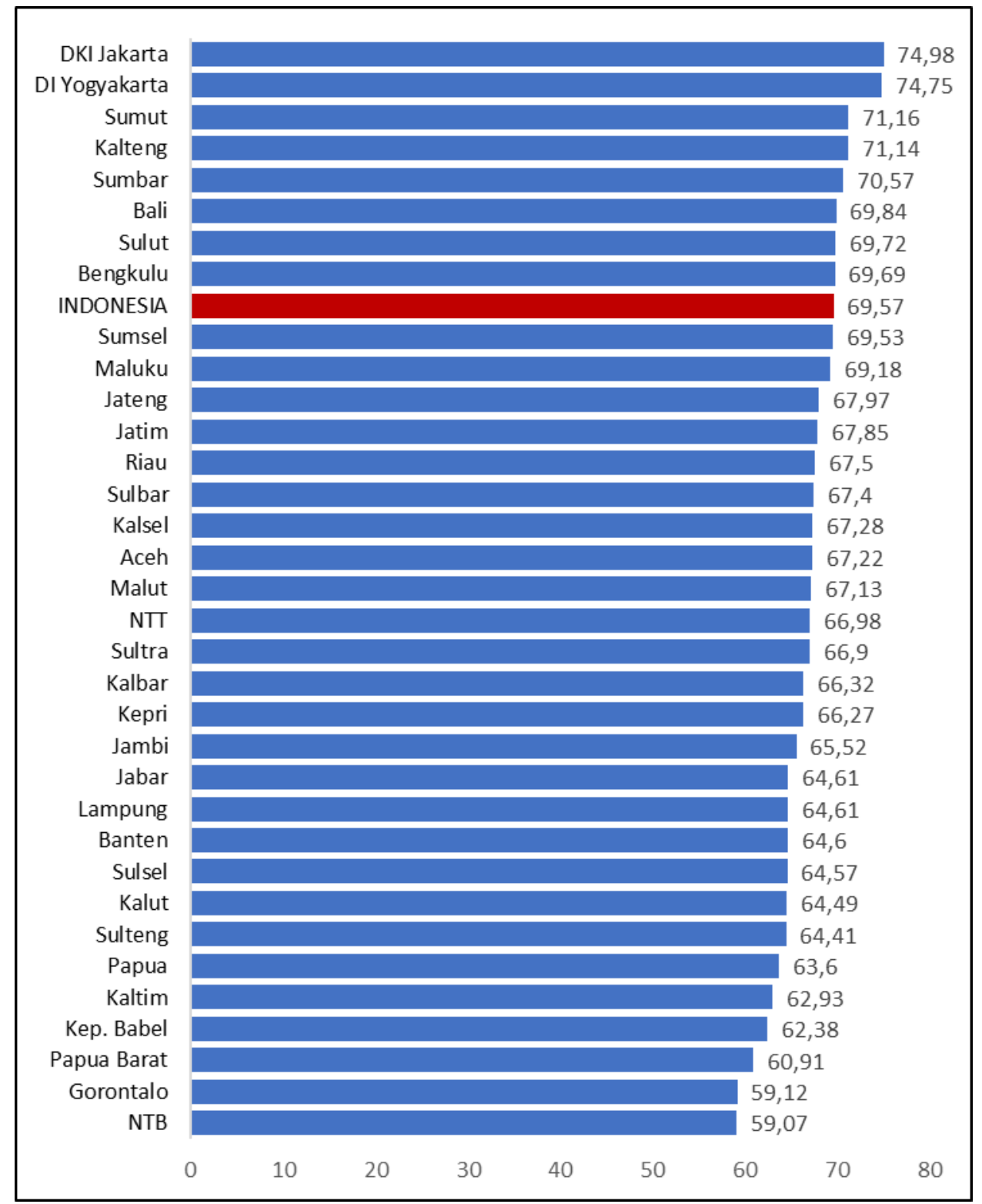

Gambar 1. Indeks Pembangunan Gender menurut Provinsi, 2013

Pada bidang politik, kesetaraan gender juga dirasakan belum terpenuhi dengan baik. Terbukti data dari hasil Pemilu 1955-2014 menunjukkan bahwa kiprah perempuan di bidang politik masih belum memenuhi harapan, yaitu tercapainya 30 persen keterwakilan (Statistik Indonesia, 2017). Bahkan dari 34 provinsi, tidak ada satu pun provinsi yang memenuhi 30 persen keterwakilan perempuan dalam komposisi anggota legislatifnya sampai dengan tahun 2015 (Kementerian Dalam Negeri, 2015). Pada tahun 2016, provinsi Sulawesi Utara menjadi satu-satunya provinsi yang memenuhi bahkan melampaui 30 persen keterwakilan perempuan dalam komposisi anggota legislatifnya (37,78 persen) meskipun melalui Penggantian Antar Waktu (PAW). 
Terkait isu kesetaraan gender dan pencapaian SDGs, kepemimpinan perempuan (women's leadership) adalah hal penting untuk mencapai dan mempercepat tercapainya SDGs. Sayangnya belum ada penelitian tentang kepemimpinan wanita yang mencakup seluruh wilayah Indonesia. Oleh karena itu penelitian ini bertujuan mengukur kepemimpinan perempuan menggunakan metode Fuzzy C-Mean Clustering (FCM). Metode FCM dipilih karena merupakan salah satu metode analisis pengelompokkan yang sering dipakai peneliti. Kepemimpinan perempuan akan diukur dalam 5 dimensi yaitu bidang politik, pemerintahan, pendidikan, ekonomi dan pengambilan keputusan.

Artikel ini disusun sebagai berikut, latar belakang penelitian diulas pada bagian pertama. Bagian kedua mendiskusikan konsep kepemimpinan perempuan. Bagian ketiga menjelaskan sumber data dan metodologi yang digunakan dalam penelitian ini. Bagian keempat membahas temuan-temuan dan bagian kelima memberikan kesimpulan serta rekomendasi untuk berbagai kebijakan program.

\section{KONSEP KEPEMIMPINAN PEREMPUAN}

Kepemimpinan perempuan sudah menjadi isu publik yang selalu menarik perhatian. Banyak fakta yang dapat dilihat pada masa sekarang bahwa perempuan telah banyak mengambil bagian di berbagai aspek kehidupan. Bahkan banyak diantara mereka yang telah menjadi pemimpin untuk sebuah kelompok tertentu. Harold Koontz and Cyril O'Donnell (1984) dalam Faraz (2013) menyatakan bahwa "leadership is influencing people the follow in the achievement of a common goal". Hand book of leadership memberikan definisi kepemimpinan sebagai suatu interaksi antar anggota suatu kelompok. Pemimpin merupakan agen perubahan, orang yang perilakunya akan lebih mempengaruhi orang lain daripada perilaku orang lain yang mempengaruhi mereka. Kepemimpinan timbul ketika suatu anggota kelompok mengubah motivasi atau kompetensi anggota lainnya didalam kelompok. Dengan demikian dapat disimpulkan bahwa kepemimpinan perempuan merupakan suatu proses atau kegiatan untuk mempengaruhi orang atau sekelompok orang anggota organisasi untuk mencapai tujuan bersama yang dilakukan oleh perempuan.

Kepemimpinan bukan semata-mata kekuasaan yang kebanyakan berujung pada kemudahan fasilitas dan kemudahan mengakses kebijakan secara cepat dan mudah. Maka kepemimpinan bukan saja tugas kaum laki-laki tetapi juga kaum perempuan. Perempuan juga mempunyai tanggungjawab kepemimpinan pada level manapun. Setiap orang bisa menjadi pemimpin pada level apapun, baik sebagai pemimpin pemerintahan, lembaga maupun masyarakat (Suyatno, 2014).

Kepemimpinan perempuan tidak hanya terbatas dalam kehidupan rumah tangga, tetapi juga dalam masyarakat. Peran domestik perempuan yang sifatnya kodrati seperti hamil, melahirkan, menyusui dan lain-lain memang tidak mungkin digantikan oleh laki-laki. Akan tetapi dalam peran publik, perempuan sebagai anggota masyarakat dan warga negara mempunyai hak untuk mengemukakan pendapat, berpolitik dan melakukan peran sosialnya yang lebih tegas dan transparan. Dalam peran publik, perempuan memiliki berbagai aktivitas yang bersifat peran sosial, budaya, politik, ekonomi dan sebagainya (Suyatno, 2014). Dalam ranah domestik yaitu urusan rumah tangga, bukan hanya kaum laki-laki saja yang menjadi pemimpin, kaum perempuanpun juga memiliki tugas memimpin urusan rumah tangganya. Bahkan ada beberapa keadaaan yang mengharuskan perempuan berperan sebagi pemimpin keluarga sekaligus sebagai pengambil kebijakan di keluarga, misalnya pada single parent.

Sudah banyak kaum perempuan yang dapat mengenyam dunia pendidikan yang sejajar dengan kaum laki-laki sehingga dapat menduduki jabatan strategis dalam pemerintahan. Perempuan Indonesia benar-benar muncul mengambil peranan strategis kepemimpinan dalam pemerintahan. Indonesia pernah mempercayakan kepemimpinan seorang presiden berjenis kelamin perempuan, yaitu Megawati Soekarno Putri. Selain itu ada Tri Rismaharini sebagai Walikota Surabaya dan Bupati Minahasa Selatan Tetty Paruntu. Selain itu, perempuan Indonesia juga memiliki peranan dalam pembangunan di bidang politik baik terlibat dalam kepartaian, legislatif maupun dalam pemerintahan. Partisipasi dalam bidang politik ini tidaklah semata-mata hanya sekedar pelengkap saja melainkan harus berperan aktif dalam pengambilan keputusan politik yang menyangkut kepentingan negara dan bangsa. Hak suara perempuan memiliki kesejajaran dengan laki-laki dalam mengambil keputusan politik baik dalam pemilihan umum ataupun ketika duduk sebagai anggota partai politik (Pasya, 2015). 
104 Sukim, dkk.

Dalam bidang ekonomi, kiprah perempuan Indonesia sudah tidak diragukan lagi. Dalam satu dekade terahir ini perempuan seolah menjadi bintang dalam upaya pengentasan kemiskinan. Berbicara mengenai ekonomi adalah juga berbicara mengenai perempuan, sebab kenyataannya, perempuan adalah agent of development yang perannya sangat dibutuhkan dalam perkembangan perekonomian. Keberdayaan wanita di bidang ekonomi adalah salah satu indikator meningkatnya kesejahteraan. Saat wanita menjadi kaum terdidik, mempunyai hakhak kepemilikan, dan bebas untuk bekerja di luar rumah serta mempunyai pendapatan mandiri, inilah tanda kesejahteraan rumah tangga meningkat.

\section{SUMBER DATA DAN METODOLOGI}

Data yang digunakan dalam penelitian ini berasal dari berbagai sumber yaitu hasil survei penduduk antar sensus $2015\left(\mathrm{X}_{3}, \mathrm{X}_{4}\right.$ dan $\left.\mathrm{X}_{5}\right)$. Sedangkan $\mathrm{X}_{1}$ dan $\mathrm{X}_{2}$ berasal dari data Kementrian dalam Negeri. Secara jelasnya variabel penelitian dijelaskan pada Tabel 1 sebagai berikut:

Tabe1 1. Variabel Penelitian dan Deskripsinya

\begin{tabular}{|c|c|c|}
\hline $\begin{array}{l}\text { Variabel } \\
\text { Penelitian }\end{array}$ & Dimensi & Deskripsi \\
\hline $\mathrm{X}_{1}$ & Politik & $\begin{array}{l}\text { Persentase perempuan yang menjadi anggota legislatif } \\
\text { pada tingkat provinsi }\end{array}$ \\
\hline $\mathrm{X}_{2}$ & Pemerintahan & $\begin{array}{l}\text { Persentase perempuan yang menjadi kepala daerah } \\
\text { (Gubernur, wakil gubernur, bupati, wakil bupati, } \\
\text { walikota dan wakil walikota) }\end{array}$ \\
\hline $\mathrm{X}_{3}$ & Pendidikan & $\begin{array}{l}\text { Persentase penduduk perempuan usia } 5 \text { tahun ke atas } \\
\text { yang berpendidikan tertinggi SLTA ke atas pada tingkat } \\
\text { provinsi }\end{array}$ \\
\hline $\mathrm{X}_{4}$ & Ekonomi & $\begin{array}{l}\text { Persentase perempuan yang berusaha dibantu dengan } \\
\text { buruh tetap pada tingkat provinsi }\end{array}$ \\
\hline $\mathrm{X}_{5}$ & $\begin{array}{l}\text { Pengambil } \\
\text { Keputusan }\end{array}$ & $\begin{array}{l}\text { Persentase Kepala Rumah Tangga Perempuan pada } \\
\text { tingkat provinsi }\end{array}$ \\
\hline
\end{tabular}

FCM merupakan salah satu metode pengelompokan (clustering) yang mengizinkan setiap observasi memiliki derajat keanggotaan pada cluster yang terbentuk (dalam penelitian ini unit observasi adalah provinsi). Di mana setiap provinsi memiliki derajat keanggotaan dalam cluster yang terbentuk dengan nilai antara 0 s.d. 1.

Langkah-langkah yang digunakan dalam penelitian ini yaitu mengaplikasikan metode Fuzzy CMean (FCM) Cluster, standarisasi data, mengelompokkan data dengan mencoba berbagai nilai $\mathrm{C}$, untuk mendapatkan jumlah cluster optimum digunakan ukuran indeks validitas, dan menganalisis hasil pengelompokkan yang terbentuk. Sedangkan alat bantu komputer yang digunakan adalah berupa piranti lunak (software) yang terkait dengan pengolahan dan analisis statistik yaitu R-Cluzzy. R-Cluzzy merupakan paket program hasil karya mahasiswa STIS. Dari hasil pengolahan data disimpulkan cluster ideal yang terbentuk berdasarkan indeks validitas yang digunakan.

Tahapan dalam penelitian ini dilakukan berdasar pada tujuan penelitian yang meliputi:

1. Mengaplikasikan algoritma FCM.

2. Melakukan analisis statistik deskriptif

3. Melakukan preprosesing, meliputi menyusun matriks ukuran $N$ x $p$, di mana $N$ adalah banyaknya observasi (banyaknya Provinsi) dan $\mathrm{p}$ adalah banyaknya variabel atau atribut data (dimensi data), yaitu matriks ukuran 34 x 5 untuk 34 provinsi seluruh Indonesia.

4. Melakukan pengelompokkan dengan Metode FCM Clustering

a. Formula optimasi fungsi objektif yang diberikan sebagai berikut 


$$
J(X, U, V)=\sum_{k=1}^{N} \sum_{i=1}^{C}\left(u_{i k}\right)^{m} D\left(x_{k}, v_{i}\right)^{2}
$$

di mana $u_{i k}$ adalah matriks keanggotaan observasi ke-k pada cluster ke-i dan $v_{i}$ adalah pusat cluster ke-i.

b. Menguji konvergensi algoritma FCM, yaitu menetapkan kondisi konvergen, menganalisis kondisi konvergen, mendapatkan kondisi matriks jarak

5. Melakukan Analisis data hasil clustering 34 provinsi di Indonesia.

a. Melakukan clustering dari mulai $C=2$ sampai $C=4$, kemudian dengan melihat nilai indeks validitas yang digunakan untuk memperoleh gambaran jumlah cluster optimum.

b. Menentukan faktor fuzzy (weigthing exponent) hasil pengelompokkan $(m)$. Belum ada satu teori pun yang menjastifikasi (justification) nilai $m$ berapa. Pada penelitian ini digunakan $m=2$, sebagaimana telah umum diterapkan dalam banyak penelitian terdahulu (Zimmermann dalam Naik (2004)).

c. Menghitung fuzzy centroid cluster ( $\left.V_{i}\right)$ dengan persamaan (2)

$$
v_{i}=\frac{\sum_{k=1}^{N} u_{i k}{ }^{m} x_{k}}{\sum_{k=1}^{N} u_{i k}{ }^{m}}
$$

d. Memperbaharui anggota matriks $\boldsymbol{U}$ dengan persamaan (3)

$$
u_{i k}=\left[\sum_{j=1}^{C}\left(\frac{D\left(x_{k}, v_{i}\right)}{D\left(x_{k}, v_{j}\right)}\right)^{\frac{2}{m-1}}\right]^{-1}
$$

e. Membandingkan nilai keanggotaan dalam matriks $\boldsymbol{U}$, jika sudah tidak banyak mengalami perubahan berarti konvergen dan kondisi keanggotaannya sudah optimum nilai mutlak dari $\left(\boldsymbol{U}_{k+1}-\boldsymbol{U}_{k}\right)<$ threshold yang ditetapkan). Iterasi dihentikan dan didapatkan hasil pengelompokkan. Jika belum terpenuhi kondisi optimum kembali ke langkah 5c.

6. Melakukan perhitungan indeks validitas clustering. Ada beberapa indeks validitas yang digunakan. Pada penelitian ini digunakan tujuh indeks validitas (Partition Coefficient, Modified Partition Coefficient, Classification Entropy, Fukuyama Sugeno, Partition Index, XieBeni's Index, dan Kwon's Index).

7. Melakukan interpretasi hasil dengan metode FCM pada kasus data kepemimpinan perempuan di 34 Provinsi seluruh Indonesia.

\section{HASIL DAN PEMBAHASAN}

Hasil pengolahan data dengan menggunakan package $R$-Cluzzy menunjukkan bahwa pengelompokan wilayah provinsi menurut dimensi kepemimpinan perempuan menghasilkan 2 , 3, dan 4 kategori wilayah atau cluster.

Berdasarkan Tabel 2 dan Tabel 3. Hasil pengolahan dengan $\mathrm{C}=2, \mathrm{~m}=2$ didapatkan pengelompokan wilayah Provinsi sebagai berikut: Wilayah Provinsi yang masuk ke dalam cluster pertama adalah provinsi yang memiliki karakteristik rendah pada kelima dimensi (politik, pemerintahan, pendidikan, ekonomi, dan pengambil keputusan). Anggota cluster pertama (lihat Tabel 4.) ada 24 provinsi yaitu semua provinsi di Pulau Sumatera kecuali Bengkulu, semua provinsi di Pulau Sulawesi kecuali Sulawesi Utara, seluruh provinsi di Pulau Kalimantan kecuali Kalimantan Tengah dan Kalimantan Utara, seluruh provinsi di Pulau Papua, Nusa Tenggara, DKI Jakarta, dan Maluku Utara. Cluster kedua (Tabel 5.) terdiri dari 10 provinsi di luar cluster pertama. 
106 Sukim, dkk.

Tabel 2. Matriks Pusat Cluster $\mathrm{C}=2, \mathrm{~m}=2$

\begin{tabular}{cccccc}
\hline Cluster & \multicolumn{5}{c}{ Variabel } \\
\cline { 2 - 6 } Center & $\mathbf{X}_{\mathbf{1}}$ & $\mathbf{X}_{\mathbf{2}}$ & $\mathbf{X}_{\mathbf{3}}$ & $\mathbf{X}_{\mathbf{4}}$ & $\mathbf{X}_{\mathbf{5}}$ \\
\hline Center 1 & 13.37 & 2.19 & 11.89 & 0.29 & 3.48 \\
Center 2 & 20.86 & 10.88 & 12.22 & 0.33 & 3.63 \\
\hline
\end{tabular}

Tabel 3. Matriks keanggotaan dengan $\mathrm{C}=2, \mathrm{~m}=2$

\begin{tabular}{|c|c|c|c|c|c|}
\hline Nama Provinsi & Cluster 1 & Cluster 2 & Nama Provinsi & Cluster 1 & Cluster 2 \\
\hline Aceh & 0.937 & 0.063 & Nusa Tenggara Barat & 0.898 & 0.102 \\
\hline Sumatera Utara & 0.913 & 0.087 & Nusa Tenggara Timur & 0.871 & 0.129 \\
\hline Sumatera Barat & 0.938 & 0.062 & Kalimantan Barat & 0.864 & 0.136 \\
\hline Riau & 0.526 & 0.474 & Kalimantan Tengah & 0.421 & 0.579 \\
\hline Jambi & 0.969 & 0.031 & Kalimantan Selatan & 0.943 & 0.057 \\
\hline Sumatera Selatan & 0.692 & 0.308 & Kalimantan Timur & 0.812 & 0.188 \\
\hline Bengkulu & 0.109 & 0.891 & Kalimantan Utara & 0.252 & 0.748 \\
\hline Lampung & 0.804 & 0.196 & Sulawesi Utara & 0.191 & 0.809 \\
\hline Kep. Bangka Belitung & 0.929 & 0.071 & Sulawesi Tengah & 0.687 & 0.313 \\
\hline Kepulauan Riau & 0.826 & 0.174 & Sulawesi Selatan & 0.704 & 0.296 \\
\hline DKI Jakarta & 0.574 & 0.426 & Sulawesi Tenggara & 0.504 & 0.496 \\
\hline Jawa Barat & 0.131 & 0.869 & Gorontalo & 0.545 & 0.455 \\
\hline Jawa Tengah & 0.068 & 0.932 & Sulawesi Barat & 0.647 & 0.353 \\
\hline D.I.Yogyakarta & 0.309 & 0.691 & Maluku & 0.307 & 0.693 \\
\hline Jawa Timur & 0.243 & 0.757 & Maluku Utara & 0.942 & 0.058 \\
\hline Banten & 0.238 & 0.762 & Papua Barat & 0.915 & 0.085 \\
\hline Bali & 0.833 & 0.167 & Papua & 0.879 & 0.121 \\
\hline
\end{tabular}

Tabel 4. Provinsi yang masuk cluster pertama

\begin{tabular}{lccccc}
\hline Nama Provinsi & $\mathbf{X}_{\mathbf{1}}$ & $\mathbf{X}_{\mathbf{2}}$ & $\mathbf{X}_{\mathbf{3}}$ & $\mathbf{X}_{\mathbf{4}}$ & $\mathbf{X}_{\mathbf{5}}$ \\
\hline Aceh & 11.03 & 2.17 & 13.94 & 0.40 & 4.99 \\
Sumatera Utara & 15.36 & 1.54 & 14.55 & 0.37 & 4.00 \\
Sumatera Barat & 11.24 & 0.00 & 13.97 & 0.31 & 4.17 \\
Riau & 23.85 & 0.00 & 12.40 & 0.28 & 2.73 \\
Jambi & 13.71 & 0.00 & 11.25 & 0.28 & 3.00 \\
Sumatera Selatan & 16.08 & 5.88 & 10.83 & 0.34 & 2.96 \\
Lampung & 16.88 & 3.33 & 9.51 & 0.31 & 2.82 \\
Kep. Bangka Belitung & 10.00 & 0.00 & 10.46 & 0.30 & 3.08 \\
Kepulauan Riau & 13.33 & 0.00 & 18.17 & 0.27 & 3.48 \\
DKI Jakarta & 21.00 & 0.00 & 20.76 & 0.46 & 4.21 \\
Bali & 8.48 & 5.00 & 14.43 & 0.53 & 2.67 \\
Nusa Tenggara Barat & 10.07 & 0.00 & 9.98 & 0.33 & 6.43 \\
Nusa Tenggara Timur & 8.51 & 0.00 & 8.17 & 0.11 & 4.00 \\
Kalimantan Barat & 9.02 & 3.33 & 8.29 & 0.27 & 2.94 \\
Kalimantan Selatan & 14.59 & 0.00 & 10.10 & 0.32 & 3.99 \\
Kalimantan Timur & 15.46 & 4.76 & 14.06 & 0.28 & 2.64 \\
Sulawesi Tengah & 18.15 & 3.85 & 11.04 & 0.25 & 2.85 \\
Sulawesi Selatan & 17.80 & 4.00 & 12.41 & 0.28 & 4.45 \\
Sulawesi Tenggara & 17.18 & 6.45 & 11.80 & 0.15 & 3.79 \\
Gorontalo & 23.34 & 0.00 & 11.23 & 0.28 & 3.21 \\
Sulawesi Barat & 13.71 & 7.69 & 8.80 & 0.15 & 3.28 \\
Maluku Utara & 10.49 & 0.00 & 11.74 & 0.19 & 2.57 \\
Papua Barat & 10.20 & 3.85 & 12.99 & 0.22 & 2.36 \\
Papua & 10.82 & 0.00 & 7.34 & 0.14 & 2.11 \\
\hline & & & & &
\end{tabular}


Tabel 5. Provinsi yang masuk cluster kedua

\begin{tabular}{lccccc}
\hline Nama Provinsi & $\mathbf{X}_{\mathbf{1}}$ & $\mathbf{X}_{\mathbf{2}}$ & $\mathbf{X}_{\mathbf{3}}$ & $\mathbf{X}_{\mathbf{4}}$ & $\mathbf{X}_{\mathbf{5}}$ \\
\hline Bengkulu & 18.52 & 9.09 & 12.21 & 0.34 & 3.01 \\
Jawa Barat & 23.00 & 17.31 & 10.56 & 0.33 & 3.94 \\
Jawa Tengah & 22.33 & 11.59 & 9.15 & 0.47 & 4.49 \\
D.I.Yogyakarta & 16.67 & 25.00 & 18.21 & 0.62 & 5.81 \\
Jawa Timur & 16.36 & 10.39 & 10.32 & 0.50 & 5.00 \\
Banten & 18.63 & 22.22 & 11.61 & 0.28 & 3.14 \\
Kalimantan Tengah & 22.60 & 3.33 & 9.90 & 0.26 & 2.62 \\
Kalimantan Utara & 17.15 & 9.09 & 10.62 & 0.12 & 2.03 \\
Sulawesi Utara & 29.63 & 12.90 & 15.69 & 0.30 & 3.37 \\
Maluku & 29.38 & 4.55 & 14.91 & 0.14 & 3.03 \\
\hline
\end{tabular}

Dengan memasang $\mathrm{C}=3$ dan $\mathrm{m}=2$, diperoleh pusat cluster sebagaimana disajikan dalam Tabel 6.

Berdasarkan Tabel 6. dan Tabel 7. Hasil pengolahan dengan $\mathrm{C}=3$, $\mathrm{m}=2$ didapatkan pengelompokan wilayah Provinsi sebagai berikut: Cluster pertama (Tabel 8.) merupakan kelompok wilayah provinsi yang meiliki karakteristik dimensi politik, pemerintahan, dan pendidikan yang sedang serta dimensi ekonomi dan pengambil keputusan yang rendah.

Sedangkan pada Cluster kedua (Tabel 9.) adalah wilayah provinsi dengan karakteristik kelima dimensi yang tinggi. Sedangkan cluster ketiga (Tabel 10.) memiliki karakteristik sedang pada dimensi ekonomi dan pengambil keputusan serta karakteristik rendah pada dimensi politik, pemerintahan, dan pendidikan.

Tabel 6. Matriks Pusat Cluster $\mathrm{C}=3, \mathrm{~m}=2$

\begin{tabular}{cccccc}
\hline \multirow{2}{*}{$\begin{array}{c}\text { Cluster } \\
\text { Center }\end{array}$} & $\mathbf{X}_{\mathbf{1}}$ & $\mathbf{X}_{\mathbf{2}}$ & $\mathbf{X}_{\mathbf{3}}$ & $\mathbf{X}_{\mathbf{4}}$ & $\mathbf{X}_{\mathbf{5}}$ \\
\cline { 2 - 6 } & 18.75 & 4.76 & 11.89 & 0.277 & 3.28 \\
Center 1 & 21.24 & 17.91 & 12.81 & 0.37 & 4.00 \\
Center 2 & 11.47 & 1.36 & 11.59 & 0.282 & 3.54 \\
Center 3 & & & & &
\end{tabular}


108 Sukim, dkk.

Tabel 7. Matriks keanggotaan dengan $\mathrm{C}=3, \mathrm{~m}=2$

\begin{tabular}{|c|c|c|c|}
\hline Nama Provinsi & Cluster 1 & Cluster 2 & Cluster 3 \\
\hline Aceh & 0.10 & 0.02 & 0.88 \\
\hline Sumatera Utara & 0.43 & 0.04 & 0.53 \\
\hline Sumatera Barat & 0.09 & 0.02 & 0.90 \\
\hline Riau & 0.68 & 0.10 & 0.21 \\
\hline Jambi & 0.13 & 0.02 & 0.86 \\
\hline Sumatera Selatan & 0.78 & 0.04 & 0.18 \\
\hline Bengkulu & 0.72 & 0.16 & 0.12 \\
\hline Lampung & 0.74 & 0.03 & 0.22 \\
\hline Kep. Bangka Belitung & 0.05 & 0.01 & 0.94 \\
\hline Kepulauan Riau & 0.32 & 0.07 & 0.61 \\
\hline DKI Jakarta & 0.53 & 0.15 & 0.32 \\
\hline Jawa Barat & 0.04 & 0.93 & 0.02 \\
\hline Jawa Tengah & 0.39 & 0.49 & 0.12 \\
\hline D.I.Yogyakarta & 0.16 & 0.72 & 0.12 \\
\hline Jawa Timur & 0.53 & 0.26 & 0.21 \\
\hline Banten & 0.08 & 0.87 & 0.05 \\
\hline Bali & 0.20 & 0.07 & 0.73 \\
\hline Nusa Tenggara Barat & 0.11 & 0.03 & 0.86 \\
\hline Nusa Tenggara Timur & 0.13 & 0.04 & 0.83 \\
\hline Kalimantan Barat & 0.15 & 0.04 & 0.80 \\
\hline Kalimantan Tengah & 0.80 & 0.08 & 0.13 \\
\hline Kalimantan Selatan & 0.24 & 0.03 & 0.74 \\
\hline Kalimantan Timur & 0.65 & 0.05 & 0.30 \\
\hline Kalimantan Utara & 0.67 & 0.16 & 0.17 \\
\hline Sulawesi Utara & 0.30 & 0.57 & 0.12 \\
\hline Sulawesi Tengah & 0.95 & 0.01 & 0.04 \\
\hline Sulawesi Selatan & 0.93 & 0.01 & 0.06 \\
\hline Sulawesi Tenggara & 0.88 & 0.03 & 0.08 \\
\hline Gorontalo & 0.69 & 0.09 & 0.21 \\
\hline Sulawesi Barat & 0.48 & 0.12 & 0.40 \\
\hline Maluku & 0.54 & 0.26 & 0.19 \\
\hline Maluku Utara & 0.04 & 0.01 & 0.95 \\
\hline Papua Barat & 0.12 & 0.03 & 0.85 \\
\hline Papua & 0.17 & 0.04 & 0.80 \\
\hline
\end{tabular}

Tabe1 8. Wilayah Provinsi yang masuk Cluster Pertama

\begin{tabular}{lccccc}
\hline Nama Provinsi & $\mathbf{X}_{\mathbf{1}}$ & $\mathbf{X}_{\mathbf{2}}$ & $\mathbf{X}_{\mathbf{3}}$ & $\mathbf{X}_{\mathbf{4}}$ & $\mathbf{X}_{\mathbf{5}}$ \\
\hline Riau & 23.85 & 0.00 & 12.40 & 0.28 & 2.73 \\
Sumatera Selatan & 16.08 & 5.88 & 10.83 & 0.34 & 2.96 \\
Bengkulu & 18.52 & 9.09 & 12.21 & 0.34 & 3.01 \\
Lampung & 16.88 & 3.33 & 9.51 & 0.31 & 2.82 \\
DKI Jakarta & 21.00 & 0.00 & 20.76 & 0.46 & 4.21 \\
Jawa Timur & 16.36 & 10.39 & 10.32 & 0.50 & 5.00 \\
Kalimantan Tengah & 22.60 & 3.33 & 9.90 & 0.26 & 2.62 \\
Kalimantan Timur & 15.46 & 4.76 & 14.06 & 0.28 & 2.64 \\
Kalimantan Utara & 17.15 & 9.09 & 10.62 & 0.12 & 2.03 \\
Sulawesi Tengah & 18.15 & 3.85 & 11.04 & 0.25 & 2.85 \\
Sulawesi Selatan & 17.80 & 4.00 & 12.41 & 0.28 & 4.45 \\
Sulawesi Tenggara & 17.18 & 6.45 & 11.80 & 0.15 & 3.79 \\
Gorontalo & 23.34 & 0.00 & 11.23 & 0.28 & 3.21 \\
Sulawesi Barat & 13.71 & 7.69 & 8.80 & 0.15 & 3.28 \\
Maluku & 29.38 & 4.55 & 14.91 & 0.14 & 3.03 \\
\hline
\end{tabular}


Tabe1 9. Wilayah Provinsi yang masuk Cluster Kedua

\begin{tabular}{lccccc}
\hline Nama Provinsi & $\mathbf{X}_{\mathbf{1}}$ & $\mathbf{x}_{\mathbf{2}}$ & $\mathbf{X}_{\mathbf{3}}$ & $\mathbf{X}_{\mathbf{4}}$ & $\mathbf{x}_{\mathbf{5}}$ \\
\hline Jawa Barat & 23.00 & 17.31 & 10.56 & 0.33 & 3.94 \\
Jawa Tengah & 22.33 & 11.59 & 9.15 & 0.47 & 4.49 \\
D.I.Yogyakarta & 16.67 & 25.00 & 18.21 & 0.62 & 5.81 \\
Banten & 18.63 & 22.22 & 11.61 & 0.28 & 3.14 \\
Sulawesi Utara & 29.63 & 12.90 & 15.69 & 0.30 & 3.37 \\
\hline
\end{tabular}

Tabel 10. Wilayah Provinsi yang masuk Cluster Ketiga

\begin{tabular}{lccccc}
\hline Nama Provinsi & $\mathbf{X}_{\mathbf{1}}$ & $\mathbf{X}_{\mathbf{2}}$ & $\mathbf{X}_{\mathbf{3}}$ & $\mathbf{X}_{\mathbf{4}}$ & $\mathbf{X}_{\mathbf{5}}$ \\
\hline Aceh & 11.03 & 2.17 & 13.94 & 0.40 & 4.99 \\
Sumatera Utara & 15.36 & 1.54 & 14.55 & 0.37 & 4.00 \\
Sumatera Barat & 11.24 & 0.00 & 13.97 & 0.31 & 4.17 \\
Jambi & 13.71 & 0.00 & 11.25 & 0.28 & 3.00 \\
Kep. Bangka Belitung & 10.00 & 0.00 & 10.46 & 0.30 & 3.08 \\
Kepulauan Riau & 13.33 & 0.00 & 18.17 & 0.27 & 3.48 \\
Bali & 8.48 & 5.00 & 14.43 & 0.53 & 2.67 \\
Nusa Tenggara Barat & 10.07 & 0.00 & 9.98 & 0.33 & 6.43 \\
Nusa Tenggara Timur & 8.51 & 0.00 & 8.17 & 0.11 & 4.00 \\
Kalimantan Barat & 9.02 & 3.33 & 8.29 & 0.27 & 2.94 \\
Kalimantan Selatan & 14.59 & 0.00 & 10.10 & 0.32 & 3.99 \\
Maluku Utara & 10.49 & 0.00 & 11.74 & 0.19 & 2.57 \\
Papua Barat & 10.20 & 3.85 & 12.99 & 0.22 & 2.36 \\
Papua & 10.82 & 0.00 & 7.34 & 0.14 & 2.11 \\
\hline
\end{tabular}

Berdasarkan Tabel 11. dan Tabel 12., hasil pengolahan dengan $\mathrm{C}=4, \mathrm{~m}=2$ didapatkan pengelompokan wilayah Provinsi sebagai berikut:

Tabel 11. Matriks pusat cluster dengan $C=4, m=2$

\begin{tabular}{rccccc}
\hline $\begin{array}{r}\text { Cluster } \\
\text { Center }\end{array}$ & $\mathbf{X}_{\mathbf{1}}$ & $\mathbf{X}_{\mathbf{2}}$ & $\mathbf{X}_{\mathbf{3}}$ & $\mathbf{X}_{\mathbf{4}}$ & $\mathbf{X}_{\mathbf{5}}$ \\
\cline { 2 - 6 } & 23.625 & 2.195 & 12.677 & 0.276 & 3.082 \\
Center 1 & 16.906 & 6.281 & 11.490 & 0.275 & 3.330 \\
Center 2 & 19.761 & 20.679 & 13.242 & 0.388 & 4.088 \\
Center 3 & 11.048 & 1.101 & 11.411 & 0.278 & 3.561 \\
\hline
\end{tabular}


110 Sukim, dkk.

Tabel 12. Matriks keanggotaan dengan $\mathrm{C}=4, \mathrm{~m}=2$

\begin{tabular}{lcccc}
\hline Nama Provinsi & Cluster $\mathbf{1}$ & Cluster 2 & Cluster 3 & Cluster 4 \\
\hline Aceh & 0.05 & 0.13 & 0.02 & 0.81 \\
Sumatera Utara & 0.17 & 0.36 & 0.03 & 0.43 \\
Sumatera Barat & 0.04 & 0.09 & 0.01 & 0.85 \\
Riau & 0.91 & 0.05 & 0.01 & 0.03 \\
Jambi & 0.06 & 0.14 & 0.01 & 0.78 \\
Sumatera Selatan & 0.02 & 0.95 & 0.01 & 0.03 \\
Bengkulu & 0.11 & 0.76 & 0.06 & 0.07 \\
Lampung & 0.14 & 0.64 & 0.03 & 0.19 \\
Kep. Bangka Belitung & 0.02 & 0.04 & 0.01 & 0.94 \\
Kepulauan Riau & 0.18 & 0.27 & 0.05 & 0.50 \\
DKI Jakarta & 0.47 & 0.26 & 0.08 & 0.20 \\
Jawa Barat & 0.09 & 0.13 & 0.73 & 0.05 \\
Jawa Tengah & 0.25 & 0.40 & 0.24 & 0.11 \\
D.I.Yogyakarta & 0.07 & 0.11 & 0.76 & 0.06 \\
Jawa Timur & 0.11 & 0.66 & 0.11 & 0.12 \\
Banten & 0.02 & 0.03 & 0.94 & 0.01 \\
Bali & 0.08 & 0.24 & 0.05 & 0.62 \\
Nusa Tenggara Barat & 0.05 & 0.10 & 0.02 & 0.83 \\
Nusa Tenggara Timur & 0.06 & 0.12 & 0.03 & 0.80 \\
Kalimantan Barat & 0.06 & 0.17 & 0.03 & 0.73 \\
Kalimantan Tengah & 0.75 & 0.17 & 0.02 & 0.05 \\
Kalimantan Selatan & 0.11 & 0.22 & 0.02 & 0.65 \\
Kalimantan Timur & 0.10 & 0.68 & 0.03 & 0.19 \\
Kalimantan Utara & 0.09 & 0.78 & 0.05 & 0.08 \\
Sulawesi Utara & 0.33 & 0.24 & 0.32 & 0.11 \\
Sulawesi Tengah & 0.16 & 0.72 & 0.02 & 0.10 \\
Sulawesi Selatan & 0.15 & 0.72 & 0.02 & 0.11 \\
Sulawesi Tenggara & 0.01 & 0.98 & 0.00 & 0.01 \\
Gorontalo & 0.87 & 0.08 & 0.01 & 0.04 \\
Sulawesi Barat & 0.09 & 0.64 & 0.06 & 0.22 \\
Maluku & 0.67 & 0.17 & 0.08 & 0.08 \\
Maluku Utara & 0.01 & 0.03 & 0.00 & 0.95 \\
Papua Barat & 0.05 & 0.17 & 0.02 & 0.75 \\
Papua & 0.07 & 0.16 & 0.03 & 0.74 \\
\hline
\end{tabular}

Wilayah provinsi yang masuk cluster pertama adalah wilayah yang memiliki karakteristik dimensi politik tinggi tetapi dimensi pengambil keputusan rendah. Sedangkan dimensi pemerintahan, pendidikan, dan ekonomi sedang. Wilayah cluster kedua memiliki ciri dimensi ekonomi yang rendah dan empat dimensi lainnya sedang.

Yang paling ekstrim adalah cluster ketiga dan keempat, di mana saling bertolak belakang. Cluster ketiga memikili ciri hanya dimensi politik sedang, empat dimensi lainnya tinggi. Sedangkan cluster keempat, memiliki ciri dimensi ekonomi dan pengambil keputusan sedang, tiga dimensi lainnya rendah. Secara umum, cluster ketiga memiliki tingkat paling tinggi untuk kelima dimensi dan cluster keempat memiliki tingkat paling rendah untuk kelima dimensi.

Tabel 13. Wilayah Provinsi yang masuk Cluster Pertama

\begin{tabular}{lccccc}
\hline \multicolumn{1}{c}{ Nama Provinsi } & $\mathbf{X 1}$ & $\mathbf{X 2}$ & $\mathbf{X 3}$ & $\mathbf{X 4}$ & $\mathbf{X 5}$ \\
\hline \multicolumn{1}{c}{$(\mathbf{1})$} & $\mathbf{( 2 )}$ & $\mathbf{( 3 )}$ & $\mathbf{( 4 )}$ & $\mathbf{( 5 )}$ & $\mathbf{( 6 )}$ \\
\hline Riau & 23.85 & 0.00 & 12.40 & 0.28 & 2.73 \\
DKI Jakarta & 21.00 & 0.00 & 20.76 & 0.46 & 4.21 \\
Kalimantan Tengah & 22.60 & 3.33 & 9.90 & 0.26 & 2.62 \\
Sulawesi Utara & 29.63 & 12.90 & 15.69 & 0.30 & 3.37 \\
Gorontalo & 23.34 & 0.00 & 11.23 & 0.28 & 3.21 \\
Maluku & 29.38 & 4.55 & 14.91 & 0.14 & 3.03 \\
\hline
\end{tabular}


Tabel 14. Wilayah Provinsi yang masuk Cluster Kedua

\begin{tabular}{lccccc}
\hline \multicolumn{1}{c}{ Nama Provinsi } & $\mathbf{X 1}$ & $\mathbf{X 2}$ & $\mathbf{X 3}$ & $\mathbf{X 4}$ & $\mathbf{X 5}$ \\
\hline Sumatera Selatan & 16.08 & 5.88 & 10.83 & 0.34 & 2.96 \\
Bengkulu & 18.52 & 9.09 & 12.21 & 0.34 & 3.01 \\
Lampung & 16.88 & 3.33 & 9.51 & 0.31 & 2.82 \\
Jawa Tengah & 22.33 & 11.59 & 9.15 & 0.47 & 4.49 \\
Jawa Timur & 16.36 & 10.39 & 10.32 & 0.50 & 5.00 \\
Kalimantan Timur & 15.46 & 4.76 & 14.06 & 0.28 & 2.64 \\
Kalimantan Utara & 17.15 & 9.09 & 10.62 & 0.12 & 2.03 \\
Sulawesi Tengah & 18.15 & 3.85 & 11.04 & 0.25 & 2.85 \\
Sulawesi Selatan & 17.80 & 4.00 & 12.41 & 0.28 & 4.45 \\
Sulawesi Tenggara & 17.18 & 6.45 & 11.80 & 0.15 & 3.79 \\
Sulawesi Barat & 13.71 & 7.69 & 8.80 & 0.15 & 3.28 \\
\hline
\end{tabular}

Tabel 15. Wilayah Provinsi yang masuk Cluster Ketiga

\begin{tabular}{lccccc}
\hline \multicolumn{1}{c}{ Nama Provinsi } & $\mathbf{X 1}$ & $\mathbf{X 2}$ & $\mathbf{X 3}$ & $\mathbf{X 4}$ & $\mathbf{X 5}$ \\
\hline \multicolumn{1}{c}{$(\mathbf{1})$} & $\mathbf{( 2 )}$ & $\mathbf{( 3 )}$ & $\mathbf{( 4 )}$ & $\mathbf{( 5 )}$ & $\mathbf{( 6 )}$ \\
\hline Jawa Barat & 23.00 & 17.31 & 10.56 & 0.33 & 3.94 \\
D.I.Yogyakarta & 16.67 & 25.00 & 18.21 & 0.62 & 5.81 \\
Banten & 18.63 & 22.22 & 11.61 & 0.28 & 3.14 \\
\hline
\end{tabular}

Tabel 16. Wilayah Provinsi yang masuk Cluster Keempat

\begin{tabular}{lccccc}
\hline \multicolumn{1}{c}{ Nama Provinsi } & $\mathbf{X 1}$ & $\mathbf{X 2}$ & $\mathbf{X 3}$ & $\mathbf{X 4}$ & $\mathbf{X 5}$ \\
\hline \multicolumn{1}{c}{$(\mathbf{1})$} & $\mathbf{( 2 )}$ & $\mathbf{( 3 )}$ & $\mathbf{( 4 )}$ & $\mathbf{( 5 )}$ & $\mathbf{( 6 )}$ \\
\hline Aceh & 11.03 & 2.17 & 13.94 & 0.40 & 4.99 \\
Sumatera Utara & 15.36 & 1.54 & 14.55 & 0.37 & 4.00 \\
Sumatera Barat & 11.24 & 0.00 & 13.97 & 0.31 & 4.17 \\
Jambi & 13.71 & 0.00 & 11.25 & 0.28 & 3.00 \\
Kep. Bangka Belitung & 10.00 & 0.00 & 10.46 & 0.30 & 3.08 \\
Kepulauan Riau & 13.33 & 0.00 & 18.17 & 0.27 & 3.48 \\
Bali & 8.48 & 5.00 & 14.43 & 0.53 & 2.67 \\
Nusa Tenggara Barat & 10.07 & 0.00 & 9.98 & 0.33 & 6.43 \\
Nusa Tenggara Timur & 8.51 & 0.00 & 8.17 & 0.11 & 4.00 \\
Kalimantan Barat & 9.02 & 3.33 & 8.29 & 0.27 & 2.94 \\
Kalimantan Selatan & 14.59 & 0.00 & 10.10 & 0.32 & 3.99 \\
Maluku Utara & 10.49 & 0.00 & 11.74 & 0.19 & 2.57 \\
Papua Barat & 10.20 & 3.85 & 12.99 & 0.22 & 2.36 \\
Papua & 10.82 & 0.00 & 7.34 & 0.14 & 2.11 \\
\hline
\end{tabular}

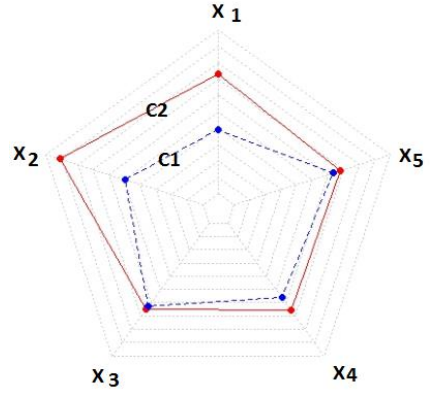

Gambar 2. Radar chart dengan $\mathrm{C}=2$

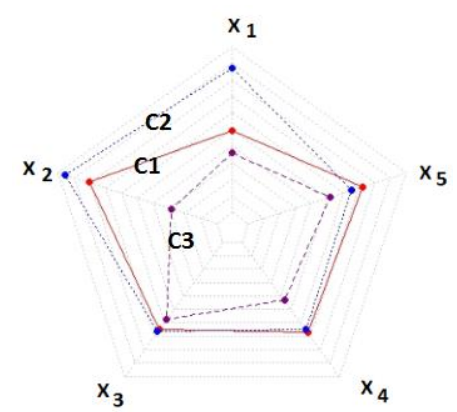

Gambar 3. Radar chart dengan $\mathrm{C}=3$

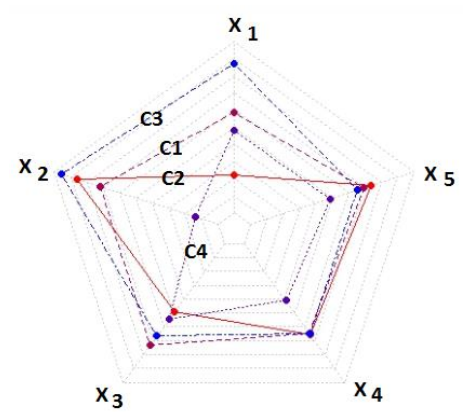

Gambar 4. Radar chart dengan $\mathrm{C}=4$ 


\section{Sukim, dkk.}

Dilihat dari Gambar 2., terlihat bahwa cluster 1 memiliki tingkat dimensi yang rendah dibandingkan dengan cluster 2 . Hanya pada dimensi pendidikan $\left(\mathrm{X}_{3}\right)$ dan dimensi ekonomi $\left(\mathrm{X}_{4}\right)$ yang relatif hampir sama.

Karakteristik wilayah provinsi apabila dikelompokan ke dalam 3 cluster dan 4 cluster sebagimana telah dijelaskan dari hasil pengolahan pada Tabel 6., Tabel 7., Tabel 11., dan Tabel 12 maka penyajian dalam radar chart seperti Gambar 3. dan Gambar 4.

\section{KESIMPULAN DAN SARAN}

\section{KESIMPULAN}

Dari hasil dan pembahasan pada bagian keempat, dapat diambil beberapa kesimpulan sebagai berikut:

1. Dengan menggunakan lima dimensi (politik, pemerintahan, pendidikan, ekonomi, dan pengambil keputusan) kepemimpinan perempuan, wilayah provinsi di Indonesia dapat dikelompokkan menjadi empat cluster opimum dari sisi ukuran tujuh indeks validitas yang digunakan.

2. Cluster pertama adalah wilayah provinsi (6 provinsi) dengan karakteristik dimensi politik yang menonjol/tinggi tetapi empat dimensi lainnya sedang. Karakteristik cluster kedua adalah wilayah provinsi (11 provinsi) yang memiliki kelima dimensinya sedang. Cluster ketiga adalah wilayah provinsi (3 provinsi) yang dimensi politiknya sedang, tetapi dimensi pemerintahan, pendidikan, ekonomi, dan dimensi pengambil keputusan tinggi. Cluster keempat merupakan wilayah provinsi (14 provinsi) yang kelima dimensinya paling rendah.

\section{SARAN}

Penelitian ini dilakukan pada level provinsi, masih perlu disempurnakan dengan membreakdown atau downscaling ke level yang lebih rendah (Kabupaten/Kota). Dimensi dan variabel yang digunakan terbatas pada 6 dimensi (politik, pemerintahan, pendidikan, ekonomi, dan pengambil keputusan) dan satu variabel untuk proksi masing-masing dimensi, masih terbuka luas untuk memilih proksi variabel atau dimensi yang lain.

\section{DAFTAR PUSTAKA}

Data dan Indikator Gender Indonesia, https://www.kemenpppa.go.id/lib/ uploads/list/ae920-bukusaku-indonesia-2015.pdf.

Faraz, Nahiyah Jaidi. 2013. Kepemimpinan perempuan. Makalah. Fakultas Ekonomi UNY.

Naik, C. Vaibhav (2004). Fuzzy C-Means Clustering Aproach to Design a Warehouse Layout, Master Thesis, Univesity of South Florida.

Pasya, Gurniwan K. Peranan Wanita dalam Kepemimpinan dan Politik. Jurnal Wanita. FPIPS UPI.

Statistik Indonesia. 2017, Publikasi BPS.

Suyatno. 2014. Kepemimpinan Perempuan (Kajian Strategis Kepemimpinan Berbasis Gender). Muwazah. Volume 6 Nomor 1. 